\title{
Revised Malaysian Shariah Screening: Its Impact on Islamic Capital Market
}

\author{
Fauzias Mat Nor ${ }^{1}$, Amir Shaharuddin ${ }^{1}$, Ainulashikin Marzuki ${ }^{1} \&$ Nur Ainna Ramli ${ }^{1}$ \\ ${ }^{1}$ Faculty of Economics and Muamalat, Universiti Sains Islam Malaysia, Bandar Baru Nilai, Negeri Sembilan, \\ Malaysia \\ Correspondence: Nur Ainna Ramli, Faculty of Economics and Muamalat, Universiti Sains Islam Malaysia, Bandar \\ Baru Nilai, 71800 Nilai, Negeri Sembilan, Malaysia. Tel: 60-6-7988-634.
}

Received: May 9, 2019

doi:10.5430/rwe.v10n1p17
Accepted: May 29, 2019

Online Published: June 9, 2019

URL: https://doi.org/10.5430/rwe.v10n1p17

\begin{abstract}
Shariah Advisory Council (SAC) of Securities Commission (SC) formulated a new revised Shariah screening methodology of two-tier quantitative assessment for activity-based screening benchmarks and the newly- formulated financial ratio benchmarks, while the qualitative assessment remains the same. The revised methodology is an effort to expand the Islamic capital market's (ICM) international reach which is in line with the SC objectives. The objective of this paper is to examine the impact of the recent announcement of new changes in the Shariah screening methodology by the Malaysian Securities Commission on the share prices of the affected companies and Islamic capital market. We use an event study method to see if the changes have a significant reaction from the market, specifically, from investors and fund managers. On the announcement date, that is, on 29 November 2013, 158 non-Shariah compliant stocks were removed from the previous list of Shariah compliant stock that was issued in May 2013 and 16 stocks were added to the approved list. Out of 158 non-Shariah compliant stocks, only 137 stocks are available for the analysis. For the new Shariah compliant stocks, only 16 stocks are included in the sample. We find an immediate but short lived negative impact on the stock returns towards the deletion, but none towards the addition of new stocks to the Shariah index. However, the announcement has no significant impact on the overall return of the FBM Emas Shariah index.
\end{abstract}

Keywords: Shariah screening, Islamic capital market, Islamic finance

\section{Introduction}

It is well-known that the performance of equity markets is essential to the economy. The efficient of the system in the equity market could generate better income to the country's economy. Due to that fact, one of the important elements to ensure the possible income to the economy is the screening methodology that classifies the Shariah and non-Shariah stocks. This is because, the classification of the particular stock would affect the performance of the volume of the stock trading and as well as the share prices. In Malaysia, particularly as a Muslim country, the status of a particular stock would affect Muslim investor's decision to invest in Shariah stocks. As compared to non-Shariah stocks, Muslim investors have no freedom in buying any stock except for Shariah compliant stocks which comply with Shariah investment requirement. Therefore, equities that are compliant with Shariah investment requirement provide confidence to Muslim investors in which leads to higher demand of Shariah stock and consequently could possibly increase the stock prices.

The essence of portfolio screening is the incorporation of ethical, social and religious values in the investment decision. The answer to whether ethical screenings are able to influence firms' financial behavior and investment portfolio lies in several theoretical arguments. First based on the work of Merton (1987), Angel and Rivoli (1997) argued that ethical screening can be considered as a kind of segmentation in the equity market where some companies are eliminated from some of the segments. The reaction to the screening depends on the comparable risk adjusted returns to unscreened funds.

Shariah screening is one aspect of incorporating of religious value. It is processes of selecting investments that are complying with the Shariah principle. Shariah outlines the activities in which Muslims are forbidden to involve with, such as riba and the consumption of alcohol. Therefore, Muslims are prohibited in investing in assets that earns returns and earnings primarily from such activities. In Malaysia, companies that listed on Bursa Malaysia can be 
classified as Shariah-compliant and Non-Shariah compliant. The determination of Shariah-compliant companies is done by Shariah Advisory Council (SAC) of the Securities Commission, Malaysia (SCM). Figure 1 shows the screening process of Shariah Advisory Council (SAC) of the Securities Commission Malaysia (SC).

SAC received input and support from the SC

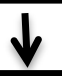

SC obtained information on the companies through, among other, audited financial report and inquiries made to the companies

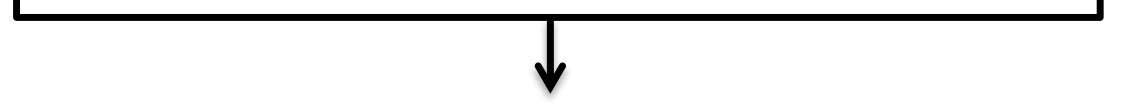

SAC, through the SC, will continue to review the Shariah status of securities listed on Bursa Malaysia, on an annual basis, based on the latest available annual audited financial statement of the companies.

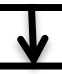

SAC will review the Shariah status of the listed securities form two-tier quantitative approach, which applies the business benchmarks and financial ratio benchmarks.

\section{$\downarrow$}

SAC will classify the securities as Shariah-compliant if the business activities and financial ratios are within the benchmarks.

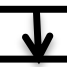

Compile the result and issue list of Shariah-compliant securities. Announcement in May and November every twice a year

Figure 1. Shariah screening method of Securities Commission, Malaysia

Source: Shariah Advisory Council (SAC) of the Securities Commission Malaysia (SC), November 2015

As compared to other screening methods employed for instance by Dow Jones Islamic Market (DJIM) and FTSE Shariah indices, the SCM's method is perceived to be lenient. The allegation lies on the different quantitative screening benchmark used by the SCM. Hence, if the Malaysian Shariah approved companies are tested using the DJIM or FTSE screening methods, there will be fewer companies qualified. Rahman et. al. (2010) found that only 35 percent of Malaysian Shariah compliant stocks qualify under DJIM's quantitative screening. Pok (2012) also tested the local Shariah compliant stocks and found that 63 percent of them qualify under FTSE criteria.

It is argued that the different screening method raises confidence issue among investors. Why there is a different benchmark in determining the lawful (halal) and unlawful (haram) status of companies? Companies which violate the Islamic law principles should remain unlawful irrespective of the localities. In an attempt to enhance the robustness of the screening methodology, SCM will revise its Shariah screening methodology which will take an effect on November 2013.

In Malaysia, the development of the Islamic financial system has increased the concerned of Halal and 'barakah' 
income earned by the Muslim investors. In general, with the reference of the equity market, Muslim investors will ensure that transaction of stock trading of buying and selling stocks are listed in Shariah-compliant securities by the Shariah Advisory Council (SAC) of Securities commission Malaysia (SC). The SAC of Securities Commission formulated a new revised Shariah screening methodology of two-tier quantitative assessment for activity-based screening benchmarks and the newly- formulated financial ratio benchmarks, while the qualitative assessment remains the same. The revised methodology is an effort to expand the Islamic capital market's (ICM) international reach which is in line with the SC initiatives.

Table 1. Comparison between previous (May 2013) and revised (November 2013) business activity benchmarks

\section{Previous Activity-Based Benchmarks (May 2013) Current Activity-Based Benchmarks} (November 2013)

$\mathbf{5 \%}$ - SAC will measure the level of mixed contribution activities that are clearly prohibited in Islam (i.e., riba-based activities, gambling, tobacco-related activities, liquor and pork; Shariah non-compliant entertainment, interest income from conventional accounts and instruments) $\mathbf{5 \%}$ - To measure the level of mixed contribution activities that are clearly prohibited in Islam.

(i) conventional banking and insurance

(ii) gambling

(iii) liquor and liquor-related activities

(iv) pork and pork-related activities;

(v) non-halal food and beverages;

(vi) Shariah non-compliant entertainment;

(vii) interest income from conventional accounts and instruments, including dividends from investment in Shariah non-compliant instruments and interest income awarded arising from a judgement of a court or arbitrator;

(viii) tobacco and tobacco-related activities; and

(ix) other activities deemed non-compliant according to Shariah

$10 \%$ - SAC will measure the level of mixture activities companies that involves matters such as "uтum balwa", 'uruf' (custom) and the rights of the non-Muslim community which are accepted by Islam.

20\% -SAC will measure the level of contribution from mixed rental payment from Shariah non-compliant activities (i.e., rental payment that involved in gambling, sale of liquor etc).

$\mathbf{2 5 \%}$ - Sac will measure the level of mixed contribution activities that basically permissible according to Shariah and consist of aspect maslahah (public interest).

- Other activities that may affect the status of Shariah compliant. Any activities that may question about their Shariah status that may deemed non-permissible according to the Shariah. Such as hotel and resort operations, share trading, stockbroking etc. $\mathbf{2 0 \%}$ - To measure the level of contribution activities of mixed rentals from Shariah non-compliant;

-To measure the level of mixed contribution activities that basically permissible according to Shariah and consist of aspect maslahah (public interest), but other activities that may affect the status of Shariah compliant is also classified under this benchmark.

\section{Financial Ratio Benchmarks}

Compute the financial ratios:

- Debt/ Total Assets;

- Cash and Cash Equivalent/

Total Assets

*Each ratio that is intended to measure riba-based elements in a company financial statements must be less than 33 percent.

Source: Malaysia Islamic financial centre (MIFC), www.mifc.com 
Table 1 shows the first-tier of the quantitative assessment of the business activity benchmarks. The new revised methodology streamlines the business activity benchmark from four benchmarks $(5 \%, 10 \%, 20 \%, 25 \%)$ to two benchmarks (5\% and 20\%). The second-tier of the quantitative assessment is the financial ratio screening. This is another improvement to the current screening methodology in which there was no screening process for the financial ratio from the previous methodology. The financial ratio will be assessed by SAC in order to measure the level of riba or riba-based elements in the company. The financial ratios consist of cash over total assets and debt over total assets. Each of the ratios above must be lower than 33\% in order to fulfil the requirements as Shariah-compliant securities (Securities Commission Malaysia, 2015).

The assessments are as follows:

\section{a) Cash and Cash Equivalent/over total assets}

The calculation will be included the cash placed in conventional accounts and instruments only. Cash placed in an Islamic account will be excluded in the calculation.

\section{b) Debt over total assets}

The calculation will be included the interest-bearing debt of the conventional accounts. Islamic financing such as sukuk that has been used by the company will be excluded in the calculation.

The revision of the screening methodology has triggered the motivation of this study. Based on the previous literature, most of the researchers scrutinize the comparison of the performance between the Shariah stocks and conventional ones. However, the study that particularly discussing the Shariah screening criterion is very rare in the literature. Even though, there are some of the studies related to Shariah stock screening (Haron \& Nursofiza, 2008; Dusuki \& Abdullah, 2009; Jamal et al., 2010; Shamsuddin, 2014; Yazi et al, 2015) yet they are not emphasizing on examining the effect of the Shariah compliance announcement of the new screening methodology towards stock price changes. In particular, how the stock prices would be affected by the results of Shariah complaint announcement (i.e, previously Shariah compliant that removed from the list and previously non-Shariah compliant but has been added to the Shariah compliant list)? This paper is different from Yazi et al. (2015) as we also investigate the impact of screening announcement on the FBM Emas Shariah index without Initial Public Offering (IPO) stocks and FBM Hijrah index as well as Islamic Equity Fund. It is believed that IPO issuance has a negative impact on the stock market return ( $\mathrm{Li}$ and Shi, 2016). In addition, we further examine the reason behind why are the stock are delisted. Therefore, the impact of the recent announcement of new changes in the Shariah screening methodology by the Malaysian Securities Commission on the share prices of the affected companies and Islamic capital market is the main objective of this study.

\section{Literature Review}

In Islamic finance system, Haron and Nursofiza (2008) stated that there are many index providers. Namely, Dow-Jones Islamic World Index (DJIM), Morgan-Stanly Compliance Islamic Index (MSCI), Financial-Times Stock Exchange Shariah Index (FTSE-SI), Standard \& Poor Shariah Index (S\&P-SI), and FTSE Bursa Malaysia Emas Shariah Index (using unique Shariah screening methodology by SAC of SC). In Malaysia, SAC was established in May 1996 under section 18 of the Securities Commission Act 1993 (SCA). The role of SCA 1993 is to safeguard the ICM with accordance to the Shariah law. Any related issues such as the development and the functions of ICM will be controlled under the SCA 1993. The qualifications of the members that represent the SAC are well-known Shariah scholars that have vast experience and knowledge related to Islamic banking, economics and finance.

Nathie (2008) argues that there will be no influenced of the equity market by the change of the Shariah compliant status. However, it is believed that the awareness of the Islamic finance has been dramatically growing from the Muslim investors. Thus, the Shariah compliant status could be one of the significant indicators for the investor to make the decision to purchase the stock.

SAC of SC will announce the list of Shariah compliant stock twice a year, which is in May and November. According to the Wong (2013), when the announcement has been made by SC on 29 November 2013, the price performance of the Shariah compliant stock that turns into non- Shariah compliant stock has declined. One situation that can explain this is due to outflow of the funds from Shariah compliant stock to non Shariah compliant investment. This situation pays attention to its importance on investigating the stock price behavior that has been announced by the SAC of SC.

Ashraf and Mohammad (2014) who studies the performance of global and regional Islamic Indices (IEIs) find that there is no abnormal return associated with the IEIs on a global basis. Dusuki and Abozaid (2007) the Muslim 
investors will decide to sell off their stock ones the stocks have turned into the non-compliant stock. This is because, if given that the demand remains the same, the investors who start to sell off the stocks would result in increases the stock's supply and consequently the stock price will go down. In contrast, if the stock turns into Shariah compliant stocks, it assumes that the investors will start to buy the stock and thus resulting increase the stock price. This indicates that switching the stock status will affect the demand and supply of the stocks and consequently affect the price determination.

\subsection{Theoretical Aspect}

There is a vast literature assessing the information content of announcements of non-screened index revisions. For example, the early studies on revisions by the S\&P 500 index include Shleifer (1986) Harris and Gurel (1986), Jain (1987), Beneish and Whaley (1996) and Lynch and Mendenhall (1997).

In general, the impact of an inclusion of a stock in an index results in a short-term positive price effect for added firms, while the impact of the exclusion of a stock from an index results in a short term negative price effect for deleted firms. There are several hypotheses have been proposed to explain such market reactions. These are i) price pressure hypothesis, ii) liquidity hypothesis, iii) information hypothesis.

Scholes (1972) proposes price pressure hypothesis to explain such market reaction. He argues that investors, including index fund managers react to index revision by performing portfolio rebalancing which leads to upward price pressure for inclusions and downward pressures for deletions. Thus, this implicates temporary price changes which should revert in the long run. Harris and Gurel (1986) support this hypothesis when they study the S\&P 500 revision from 1973 to 1983 . They find there is an immediate 3\% increase in the price of stocks that are added to the index after the announcement which then fully revert after two weeks.

Liquidity hypothesis suggests inclusion increases public information on the stock, thus reduces asymmetric information. Reduction in asymmetric information enhances stock liquidity, which is measured by the bid-ask spread, and reduces stock volatility which reflecting the reduced risk premium. This raises the attractiveness of the stock which produces a positive effect on the price.

Information hypothesis states that events such as index revision convey information about the added or deleted stocks which cause permanent price changes. Stock inclusion for example, proves the quality of stocks which increase the price of the added stocks, while stock deletion indicates below quality stocks which results in stock price reduction. This is in line with the efficient markets hypothesis where information about stocks should be reflected in the price of stocks immediately after the announcements and the information effect should be permanent. Stoll (1978), Beneish and Gardner (1995), Heflin and Shaw (2000), Hedge and McDermott (2003) and Gregoriou (2011) support Information and Liquidity Hypothesis.

Similarly, in the case of social index, the impact of Shariah index changes may produce more obvious and even stronger signaling effects. This is so because the decision to add or delete a stock for a Shariah index is unique since the selection criteria is based on whether a stock complies to Shariah or Islamic law. Even more so the deletion from Shariah index requires investors and index fund managers to immediately rebalance their portfolio, which would not happen in the case of conventional as well as social index. Literature in the market reactions to Shariah stock decomposition is limited.

Bacha and Abdullah (2001) investigate the market reaction of the Malaysian Shariah index decomposition over three-year sample period, from 1997 to 1999 which contain 39 inclusions and 21 deletions. They find that inclusion experience a positive impact while deleting is negative. Yazi et al (2015) investigate the market reaction on the recent changes in Shariah stock composition following the changes in the Shariah screening methodology announced in November 2013. Their findings support Bacha and Abdullah (2001) that inclusion of a stock in the Shariah compliant list has a positive effect on the value of the stock while removal from the list negatively affects the price of the stock.

\section{Research Methodology}

\subsection{Sample Selection}

We choose 29 November 2013 as it was when the new screening methodology was announced. On the announcement date, 158 non-Shariah compliant stocks were removed from the previous list of Shariah compliant stock that was issued in May 2013 and 16 stocks were added to the approved list. Out of 158 non-Shariah compliant stocks, only 137 stocks are available for the analysis. For the Shariah compliant stocks, only 16 stocks are included in the sample. Daily stock prices and the market indexes, namely the FTSE Burs a Malaysia EMAS Shariah (FBM 
Shariah), FTSE Bursa Malaysia KLCI (FBM KLCI) and FTSE Bursa Malaysia Hijrah (FBM Hijrah), are obtained from Datastream and Bursa Malaysia. The period ranges from 30 days before to 30 days after the announcement date.

\subsection{Method}

This study will use daily share prices of the sample securities, which will be collected from DataStream and Bursa Malaysia. Other data such as details of the companies in the index and proxy of market portfolio will also be collected from appropriated sources. In analyzing the impact of SC revised Shariah screening methodology on Malaysian capital market performance, an event study methodology will be implemented, i.e. 1 November 2013.

The performance of selected securities in the FBM Shariah index is the measure of abnormal returns. Market model approach is used in this study (MacKinlay, 1997), where FBM KLCI Index will be the proxy of the market. Consistent with Sadeghi (2008), this study uses an event window of $t=-125$ to $t=-16$ and day $t=+16$ to $t=+125$.

The return measurement under the market model is as follows:

$$
R_{i t}=\propto_{i}+\beta_{i} R_{m t}+\varepsilon_{i t}
$$

Where:

$R_{i t}=$ The return on firm $\mathrm{i}$ at time $\mathrm{t}$

$\propto_{i}=$ The intercept term with constrained $\propto=0$

$\beta_{i}=$ A parameter the measures the sensitivity of $R_{i t}$ to the market index with constrained

$\beta=1$

$R_{m t}=$ The corresponding return on the FBM KLCI Index at time $\mathrm{t}$

$\varepsilon_{i t}=$ A random variable that by construction has an expected value of zero, and is assumed to be uncorrelated with $R_{m t}$

The coefficient is based on ordinary least squares estimation.

The above equation will be used to calculate the abnormal return of each security over a test period run from $\mathrm{t}=-15$ days prior to the event date $(t=0)$, to $t=+15$ trading days after the event date. The daily abnormal returns $\left(\mathrm{AR}_{\mathrm{it}}\right)$ for security $I$ on day t of the test period will be measured as follows:

$$
A R_{i t}=R_{i t^{-}} R_{m t}
$$

In addition, the average abnormal return $\left(\mathrm{AAR}_{\mathrm{t}}\right)$ will be calculated based on the equation below:

$$
A A R_{T}=\frac{\sum_{j=1}^{N} A R_{j t}}{N}
$$

Where $\mathrm{T}$ is defined as the trading days before the event date, which is $\mathrm{T}=-15$ trading days. Statistical test will be applied to specify if individual abnormal returns differ from zero.

\section{Results and Discussion}

Table 1 shows the CAAR and the t-statistics for each of the selected event windows for stocks that are deleted from and included in the FBM Shariah index on 29 November 2013. We find that the CAAR of stocks deleted from the FBM Shariah index are negatively affected and significant for 1 and 3 days event windows while for the remaining event window, the CAAR is negative but insignificant. This indicates that the investors react quickly to the deletion announcement by switching their investment in the other Shariah compliant stocks within 3 days before and after the announcement. The results are consistent with Sadeghi (2008), Mcgowan and Muhammad (2010) and Bacha and Abdullah (2001) who find that stocks that are no longer listed as Shariah compliant would experience a decrease in share price. This is consistent with the price pressure hypothesis that there will be a selling pressure in the market which leads to pushing the stock price down. As a result, the situation will lead to a temporary deviation from the equilibrium price that would turn to negative market returns. According to Wong (2013), investors are given six months to dispose of the non-Shariah compliant stocks if the market is equal of higher than their investment cost. However, if the investment costs are higher than the market price, investors are allowed to hold the stock until its meet the breakeven (i.e., market price equal to investment cost). In this study, even though the Malaysian Securities Commission gives investors six months from the announcement to dispose of the non Shariah compliant securities, but they do not wait for that long to adjust and rebalance their Shariah compliant portfolio.

Unlike result in deletion, we find that there is no significant effect on stocks' CAAR for all event windows for 
inclusion of new stocks in the FBM Shariah index. The findings are inconsistent with Sadeghi (2008) and Mcgowan and Muhammad (2010) that report the positive impact on stock prices when the stocks are announced as Shariah compliant stocks. The possible reasons could be due to insensitivity to market towards information on new Shariah compliant stocks. Another potential reason could be there is lack of portfolio rebalancing from investors including Islamic index funds.

Table 2. Cumulative average abnormal return (CAAR) and t-statistics for selected event window (deletion and inclusion)

\begin{tabular}{ccccc}
\hline \multicolumn{3}{c}{ Cumulative Average Abnormal Return (CAAR and T-statistics for selected event window } \\
\cline { 2 - 5 } Short term & \multicolumn{3}{c}{ DELETION } & \multicolumn{2}{c}{ INCLUSION } \\
$(-1,+1)$ & -2.57006 & $-2.57653^{* *}$ & -0.59731 & -0.44073 \\
$(-3,+3)$ & -2.85161 & $-1.87152^{*}$ & -2.89567 & -1.39874 \\
$(-10,+10)$ & -4.17473 & -1.58187 & 0.232892 & 0.06495 \\
Pre announcement & & & & \\
$(-15,-1)$ & 1.34669 & -0.60377 & 3.384885 & 1.116951 \\
$(-30,-1)$ & 1.494713 & 0.494713 & 3.509995 & 0.818996 \\
Post announcement & & & & \\
$(+1,+15)$ & 0.95895 & -0.42994 & -1.39419 & -0.46006 \\
$(+1,+30)$ & 3.391557 & 1.075206 & 1.412084 & 0.329485 \\
\hline
\end{tabular}

Note: **** means statistically significant at the 5 per cent and 10 per cent levels, respectively.

Figure 2 shows the comparison of the CAAR and cumulative index return for selected event windows for deletion and inclusion of stocks in the FBMS index. This figure supports our findings that the removal of stocks from the Shariah index negatively affects the price of the stocks. In average, those stocks that were removed from the Shariah index experienced poor CAAR at least for three weeks before the price picks up again.

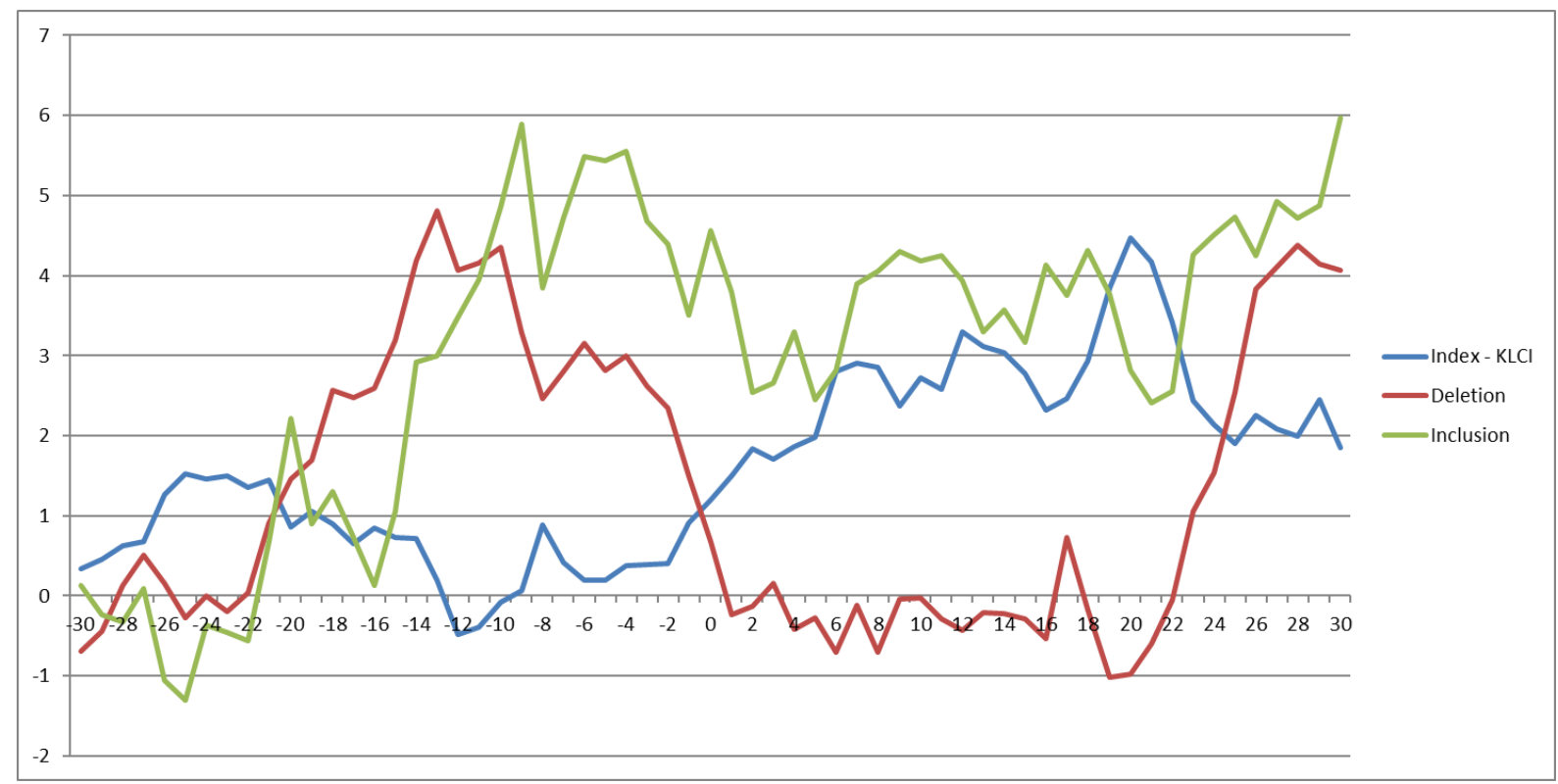

Figure 2. Comparison of the cumulative average abnormal return (CAAR) and cumulative index return for selected event window (deletion and inclusion) 
We further scrutinize the new stocks that were included in the FBMS index. IPO stocks may overshadow the effect of announcement of the addition of new Shariah compliant stocks in the FBM Shariah index. Thus, we remove all IPO stocks from the sample and analyze again to see if the results change. Table 2 shows the CAAR and the t-statistics for each of the selected event windows for stocks without IPO that are included in the FBM Shariah index on 29 November 2013. Surprisingly, none of the CAAR for all the event windows for inclusion stocks is significant.

Table 3. Cumulative average abnormal return (CAAR) and T-statistics for selected event window (inclusion without IPO)

\begin{tabular}{ccc}
\hline $\begin{array}{c}\text { Cumulative average abnormal return (CAAR) and T-statistics for selected event } \\
\text { window }\end{array}$ \\
\multicolumn{3}{c}{ INCLUSION W/0 IPO } \\
Short term & CAAR $\%$ & t-statistics \\
$(-1,+1)$ & -0.3276 & -0.19593 \\
$(-3,+3)$ & 3.60034 & -1.40966 \\
$(-10,+10)$ & 0.339161 & 0.076668 \\
Pre announcement & & \\
$(-15,-1)$ & 3.986045 & 1.066146 \\
$(-30,-1)$ & 4.864474 & 0.920016 \\
Post announcement & & -0.75967 \\
$(+1,+15)$ & 2.84021 & 0.144874 \\
$(+1,+30)$ & 0.766005 & \\
\hline
\end{tabular}

Note: $* * * *$ means statistically significant at the 5 per cent and 10 per cent levels, respectively.

Table 3 shows the CAAR and the t-statistics for each of the selected event windows for FBM Hijrah Index before and after the announcement date on 29 November 2013. Similarly, none of the CAAR for all the event windows for Islamic index FBM Hijrah is significant.

Table 4. Cumulative average abnormal return (CAAR) for FBM Hijrah and T-statistics for selected event windows

\begin{tabular}{ccc}
\hline & \multicolumn{2}{c}{ FBM Hijrah } \\
\hline Short term & $\underline{\text { CAAR \% }}$ & $\underline{\text { t-statistics }}$ \\
$(-1,+1)$ & 0.957567 & 1.174707 \\
$(-3,+3)$ & 0.98716 & 0.792793 \\
$(-10,+10)$ & 2.886001 & 1.33816 \\
Pre announcement & & \\
$(-15,-1)$ & 0.588985 & 0.323132 \\
$(-30,-1)$ & 2.208773 & 0.856863 \\
Post announcement & & \\
$(+1,+15)$ & 1.371411 & 0.75239 \\
$(+1,+30)$ & 0.438212 & 0.169998 \\
\hline
\end{tabular}

Note: **,* means statistically significant at the 5 per cent and 10 per cent levels, respectively.

Figure 3 shows the returns comparison between FBM Shariah, FBM Hijrah and FBM KLCI for selected event windows. It shows that there is also no significant difference in the return changes after the announcement date between all three indexes. It seems that the announcement does not carry much information to the market. The returns behavior of FBM Shariah and FBM Hijrah follows the returns behavior of FBM KLCI. 


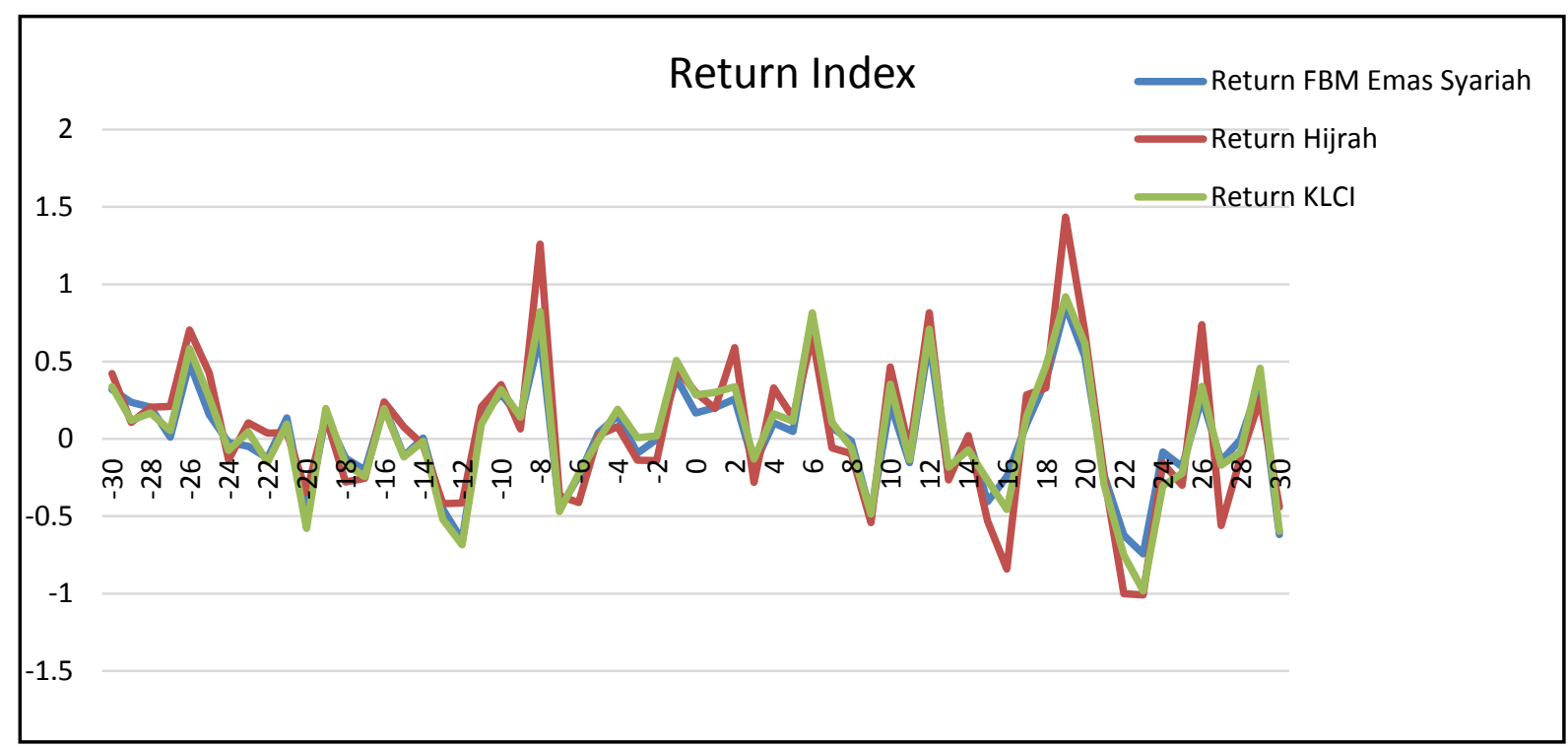

Figure 3. Return comparison between FBM Shariah, FBM Hijrah and FBM KLCI for selected event windows

Figure 4 shows the comparison of the average return, cumulative return and cumulative index return for selected event windows. It indicates that there is no significant impact of stocks inclusion and deletion exercise on the return of the FBM Hijrah index. The FBM Hijrah index is seen closely mimic the trend of FBM KLCI index.

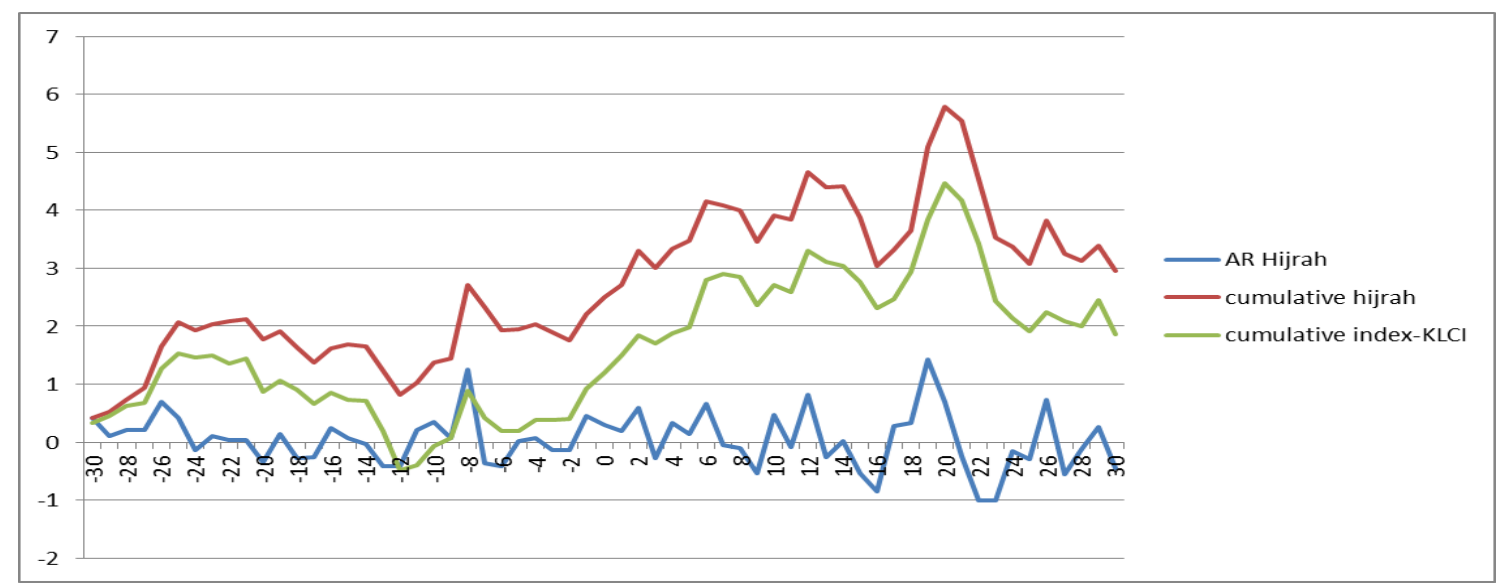

Figure 4. Comparison of the average return, cumulative return and cumulative index for selected event window (FBM Hijrah index)

Table 5 shows the CAAR and the t-statistics for each of the selected event windows for Islamic equity funds on 29 November 2013. We find that the CAAR of Islamic equity funds are negative (significant) only for the 1 and 3 days event window while the remaining event windows are insignificant. 
Table 5. Cumulative average abnormal return (CAAR) and T-statistics for selected event window (Islamic Equity funds)

\begin{tabular}{ccc}
\hline Islamic Equity (Malaysia) & & \\
\hline announcement & CAAR \% & t-statistics \\
$(-1,+1)$ & -0.7896774 & $-2.48765641^{* *}$ \\
$(-3,+3)$ & -0.8915345 & $-1.83861348^{*}$ \\
$(-10,+10)$ & -1.1755969 & -1.39974869 \\
Pre announcement & & \\
$(-15,-1)$ & 0.09123456 & 0.12445166 \\
$(-30,-1)$ & 0.75845344 & 0.74327474 \\
Post announcement & & -0.80099394 \\
$(+1,+15)$ & -0.5872025 & 0.78381977 \\
$(+1,+30)$ & 0.79982646 & \\
\hline
\end{tabular}

Note: $* * * *$ means statistically significant at the 5 per cent and 10 per cent levels, respectively.

Referring to Table 6, more than $70 \%$ of stocks were deleted due to financial ratio benchmark. This could explain why there are drastic changes in the composition of the new FBM Shariah index. The market is sensitive to the reaction of the deletion stocks as these stocks are not Shariah compliant in the sense that their debt facility and cash are not Shariah compliant.

Table 6. Reason for the deletion

\begin{tabular}{lc}
\hline \multicolumn{1}{c}{ Description } & Percentage \\
\hline Debt more than 33\% & $37 \%$ \\
Cash more than 33\% & $34 \%$ \\
Both debt and cash more than 33\% & $0.7 \%$ \\
Other factors & $20 \%$ \\
No information & $8 \%$ \\
TOTAL & $\mathbf{1 0 0 \%}$ \\
\hline
\end{tabular}

\section{Conclusion}

This paper examines the impact of the recent announcement of new changes in the Shariah screening methodology by the Malaysian Securities Commission on the Islamic capital market. The new development of a revised of Shariah screening methodology is an effort to increase the number of traders as well as playmaker in Islamic capital market's (ICM) and integrity of Islamic stock can also be strengthened. We use an event study method to see if the changes have a significant reaction from the market, specifically, from investors and fund managers. On the announcement date, that is, on 29 November 2013, 158 non-Shariah compliant stocks were removed from the previous list of Shariah compliant stock that was issued in May 2013 and 16 stocks were added to the approved list. Out of 158 non-Shariah compliant stocks, only 137 stocks are available for the analysis. For the Shariah compliant stocks, only 16 stocks are included in the sample. We find an immediate but short lived negative impact on the stock returns towards the deletion, but none towards the addition of new stocks to the Shariah index. This immediate and short lived negative impact may be due to selling off activities by individual investors. Since institutional investors are more sophisticated, the impact may be delayed as according to the Securities Commission guidelines, they have until six months after the announcement date to dispose the stocks that are removed from Shariah status. There is no significant impact on stock prices that are added to the Shariah list may be due to fact that the current portfolio is already well diversified (as there is a large number of Shariah stocks in the Shariah index) and that there are always substitutes stocks for the new stock added in the current portfolio. Thus, it may not require them to do immediate rebalancing. In addition, the announcement has no significance to the Islamic capital market, which is a proxy by 
FBM Shariah index. It is consistent with the efficient market hypothesis.

\section{References}

Abderrezak, F. (2008). The Performance of Islamic Equity Funds: A Comparison to Conventional Islamic and Ethical Benchmarks. Master of International Business Finance, University of Maastricht, Maastricht, The Netherlands.

Abdullah, F., Hassan, T., \& Mohamad, S. (2007). Investigation of Performance of Malaysia Islamic Unit Trust Funds: Comparison With Conventional Unit Trust Funds. Managerial Financial, 33(2), 142-153.

Albaity, M., \& Ahmad, R. (2008). Performance of Syariah and Composite Indices: Evidence from Bursa Malaysia. Asian Academy of Management Journal of Accounting and Finance, 4(1), 23-43.

Alexandar, G. J., \& Buchholz, R. A. (1978). Corporate Social Responsibility and Stock Market Performance. The Academy of Management Journal, 21(3), 479-486. https://doi.org/10.5465/255728

Angel, J. J., \& Rivoli, P. (1997). Does Ethical Investing Impose A Cost Upon The Firm? A Theoretical Perspective. The Journal of Investing, Winter, 57-61. https://doi.org/10.3905/joi.1997.57

Ashraf, D., \& Mohammad, N. (2014). Matching Perception with The Reality-Performance Of Islamic Equity Investments. Pacific-Basin Finance Journal, 28, 175-189. https://doi.org/10.1016/j.pacfin.2013.12.005

Bacha, Obiyathulla I., \& Abdullah, Mimi H. (2001, June). Halal Stock Designation and Impact On Price And Trading Volume. The Journal of Accounting, Commerce \& Finance - Islamic Perspective, 5(1), 66-97.

Barnea, A., Heinkel, R., \& Kraus, A. (2005). Green Investors and Corporate Investment. Structural Change and Economic Dynamic, 16(3), 332-346. https://doi.org/10.1016/j.strueco.2004.04.002

Barnett, M. L., \& Salomon, R. M. (2006). Beyond Dichotomy: The Curvilinear Relationship Between Social Responsibility And Financial Performance. Strategic Management Journal, 21(11). 1101-1122.

Bauer, R., Derwall, J., \& Otten, R. (2007). The Ethical Mutual Fund Performance Debate: New Evidence from Canada. Journal of Business Ethics, 70, 111-124. https://doi.org/10.1007/s10551-006-9099-0

Bauer, R., Guenster, N., \& Otten, R. (2004). Empirical Evidence on Corporate Governance In Europe: The Effect On Stock Returns. Firm Value and Performance. Journal of Asset Management, 5(2), 91-104.

Bauer, R., Koedijk, K., \& Otten, R. (2005). International Evidence on Ethical Mutual Fund Performance and Investment Style. Journal of Banking \& Finance, 29(7), 1751-1767.

Bauer, R., Ottem, R., \& Rad, A. T. (2006). Ethical Investing In Australia: Is There A Financial Penalty?. PacificBasin Finance Journal, 14(1), 33-48. https://doi.org/10.1016/j.pacfin.2004.12.004

Beneish and Gardner. (1995). Information Costs and Liquidity Effects From Changes In The Dow Jones Industrial Average List. Journal of Financial and Quantitative Analysis, 30(1), 135-157. https://doi.org/10.2307/2331257

Beneish, M., \& Whaley, R. (1996). An Anatomy of the 'S\&P Game': The Effects of Changing the Rules. Journal of Finance, 51, 1909-1930. https://doi.org/10.1111/j.1540-6261.1996.tb05231.x

BinMahfouz, S., \& Hassan, K. M. (2012). A Comparative Study between the Investment Characteristics of Islamic and Conventional Equity Mutual Funds In Saudi Arabia. The Journal of Investing, Winter, 128-143.

Claessens, S. (1997). Corporate Governance and Equity Prices: Evidence from the Czech and Slovak Republics. The Journal of Finance, 52(4), 1641-1658. https://doi.org/10.1111/j.1540-6261.1997.tb01124.x

Cremers, K. J. M., \& Nair, V. B. (2005). Governance Mechanisms and Equity Prices. The Journal of Finance, 60(6), 2859-2894. https://doi.org/10.1111/j.1540-6261.2005.00819.x

de Colle, S., \& York, J. G. (2009). Why Wine Is Not Glue? The Unresolved Problem of Negative Screening in Socially Responsible Investing. Journal of Business Ethics, 85(1), 83-95.

Derigs, U., \& Marzban, S. (2008). Review and Analysis of Current Shariah-Compliant Equity Screening Practices. International Journal of Islamic and Middle Eastern Finance and Management, 1(4), 285-303.

Derigs, U., \& Marzban, S. (2009). New Strategies and A New For Shariah-Compliant Portfolio Optimization. Journal of Banking and Finance, 33(6), 11. https://doi.org/10.1016/j.jbankfin.2008.12.011

Dillenburg, S., Greene, T., \& Erekson, H. (2003). Approaching Socially Responsible Investment With A Comprehensive Ratings Scheme: Total social impact. Journal of Business Ethics, 43(3), 167-177. 
Dowell, G., Hart, S., \& Yeung, B. (2000). Do Corporate Global Environmental Standards Create or Destroy Market Value?. Management Science, 46(8), 1059-1074. https://doi.org/10.1287/mnsc.46.8.1059.12030

Dusuki and Abozaid. (2007). A Critical Appraisal on The Challenges Of Relizing Maqasid Al-Shariah in Islamic Banking And Finance. International Journal of Economics, Management and Accounting, 15(2).

Dusuki, A. W., \& Abdullah, N. I. (2009). Maqasid al Shariah (Objective of Shariah) in the Islamic Capital Market: Special Focus on Equity Sukuk. ISRA Research Paper (No.5/2009).

Elfakhani, S. M., \& Hassan, M. K. (2005). Performance of Islamic Mutual Funds. Paper presented at the 12th Economic Research Forum Conference, Cairo, Egypt.

Friedman, M. (1970). The Social Responsibility of Business Is To Increase Its Profit. The New York Times Magazines, 13, 32.

Geczy, C. C., Stambaugh, R. F., \& Levin, D. (2005). Investing In Socially Responsible Mutual Funds. Social Science Research Network. Retrieved 30 August 2009, from http://ssrn.com

Girard, E., \& Hassan, M. K. (2005). Faith-Based Ethical Investing: The Case of Dow Jones Islamic Indexes FMA Papers. Retrieved 22 July 2009, from http://www.fma.org

Goldreyer, E. F., Ahmed, P., \& Diltz, J. D. (1999). The Performance of Socially Responsible Mutual Funds: Incorporating Sociopolitical Information in Portfolio Selection. Managerial Finance, 25(1), 23.

Gompers, P., Ishii, J., \& Metrick, A. (2003). Corporate Governance and Equity Prices. The Quarterly Journal of Economics, 118(1), 107-155. https://doi.org/10.1162/00335530360535162

Gregory, A., Matatko, J., \& Luther, R. (1997). Ethical Unit Trust Financial Performance: Small Company Effects and Fund Size Effects. Journal of Business and Accounting, 24(5), 705-725.

Hakim, S., \& Rashidian, M. (2002). Risk and Return Of Islamic Stock Market Indexes. Paper presented at the Economic Research Form Annual Meetings, Sharjah, UAE.

Hakim, S., \& Rashidian, M. (2004). How Costly Is Investors' Compliance To Sharia? Paper presented at the Economic research Forum Eleventh Annual Conference, Beirut.

Hamilton, S., Jo, H., \& Statman, M. (1993). Doing Well While Doing Good? The Investment Performance of Socially Responsible Mutual Funds. Financial Analysts Journal, 49(6), 62-66.

Haron, S., \& Nursofiza, W. (2008). Creating a Dynamic Islamic Capital Market. Islamic Capital Market, Products, Regulation \& Development. Islamic Development Bank, 23-32.

Harris, L., \& Gurel, E. (1986). Price And Volume Effects Associated With Changes In The S\&P 500: New Evidence For The Existence of Price Pressure. Journal of Finance, 41, 851-860.

Hayat, R. (2006). An Empirical Assessment of Islamic Equity Fund Returns. Master thesis, free University, Amsterdam, Netherlands.

Hayat, R., \& Kraeussl, R. (2011). Risk and Return Characteristics of Islamic Equity Funds. Emerging Markets Review, 12(2), 189-203. https://doi.org/10.1016/j.ememar.2011.02.002

Hedge and McDermott. (2003). The Liquidity Effects of Revisions to the S\&P500 Index: An Empirical Analysis. Journal of Financial Markets, 6(3), 413-459. https://doi.org/10.1016/S1386-4181(02)00046-0

Heflin, F., \& Shaw, W. K. (2000). Blockholder Ownership and Market Liquidity. Journal of Financial and Quantitative Analysis, 35, 621-633. https://doi.org/10.2307/2676258

Heinkel, R.., Kraus, A., \& Zechner, J. (2001). The Effect of Green Investment on Corporate Behavior. Journal of financial and Quantitative Analysis, 36(4), 431-449. https://doi.org/10.2307/2676219

Hillman, A. J., \& Keim, G. D. (2001). Shareholder Value, Stakeholder Management And Social Issues: What's The Bottom Line?. Strategic Management Journal, 2292, 125-139.

Hoepner, A. G. F., Rammal, H. G., \& Rezec, M. (2011). Islamic Mutual Funds' Financial Performance and International Investment Style: Evidence from 20 Countries. The European Journal of Finance, 17(9-10), 829-850. https://doi.org/10.1080/1351847X.2010.538521

Hong, H., \& Kacperczyk, M. (2009). The Price of Sin: The Effects of Social Norms on Markets. Journal of Financial Economics, 93(1), 15-36. https://doi.org/10.1016/j.jfineco.2008.09.001 
Humphrey, J. E., \& Lee, D. D. (2011). Australian Socially Responsible Funds: Performance, Risk and Screening Intensity. Journal of Business Ethics, 102(4), 519-535. https://doi.org/10.1007/s10551-011-0836-7

Hussein, K. A. (2005). Islamic Investment: Evidence from Dow Jones and FTSE Indices. Paper Presented at the International; Conference on Islamic Economics and Finance, Indonesia.

Hussein, K. A., \& Omran, M. (2005). Ethical Investment Revisited: Evidence From Dow Jones Islamic Indexes. The Journal of Investing, 14(3), 105-126. https://doi.org/10.3905/joi.2005.580557

Jain, P. C. (1987, January-February). The Effect on Stock Price Of Inclusion In Or Exclusion From The S\&P500. Financial Analysis Journal. https://doi.org/10.2469/faj.v43.n1.58

Jamal, J., Hambali, N., \& Ali, H. M. (2010). Islamic Capital Market and Shari'ah Screening in Malaysia. International Research Symposium in Service Management.

Jones, S., van der Laan, S., Frost, G., \& Loftus, J. (2008). The Investment Performance of Socially Responsible Investment Funds in Australia. Journal of Business Ethics, 80(2), 181-203.

Klassen, R. D., \& McLaughlin, C. P. (1996). The Impact of Environmental Management On Firm Performance. Management Science, 42(8), 1199-1214. https://doi.org/10.1287/mnsc.42.8.1199

Knoll, M. S. (2002). Ethical Screening In Modern Financial Markets: The Conflicting Claims Underlying Socially Responsible Investment. The Business Lawyer, 57(2), 681-726.

Konar, S., \& Cohen, M. A. (2001). Does The Market Value Environmental Performance?. The Review of Economics and Statistics, 83(2), 281-289. https://doi.org/10.1162/00346530151143815

Kreander, N., Gray, R. H., Power, D. M., \& Sinclair, C. D. (2005). Evaluating the Performance Of Ethical And Non-Ethical Funds: A Matched Pair Analysis. Journal of Business Finance \& Accounting, $32(7$ \& 8), 1465-1493. https://doi.org/10.1111/j.0306-686X.2005.00636.x

Langbein, J. H., \& Posner, R. A. (1980). Social Investing and the Law of Trusts. Michigan Law Review, 79(1), 72-112. https://doi.org/10.2307/1288337

Lee, D. D., Humphrey, J. E., Benson, K. L., \& Ahn, J. Y. K. (2010). Socially Responsible Investment Fund Performance: The Impact of Screening Intensity. Accounting \& Finance, 50(2), 351-370.

Li, X., \& Shi, X. (2016). The Impact Of IPO On The Secondary Market: An Empirical Research. Modern Economy, 7(3), 299-306. https://doi.org/10.4236/me.2016.73032

Luther, R. G., \& Matatko, J. (1994). The Performance of Ethical Unit Trusts: Choosing an Appropriate Benchmark. The British Accounting Review, 26(1), 77-89. https://doi.org/10.1006/bare.1994.1007

Luther, R. G., Matako, J., \& Corner, D. C. (1992). The Investment Performance of UK 'Ethical' Unit Trust. Accounting, Auditing \& Accountability Journal, 5(4), 57. https://doi.org/10.1108/09513579210019521

Lynch, W., \& Mendenhall, R. (1997). New Evidence on Stock Price Effects Associated with Changes in the S\&P 500 Index. Journal of Business, 70, 351-383. https://doi.org/10.1086/209722

MacKinlay, (1997, March). Event Studies in Economics and Finance. Journal of Economic Literature, XXXV, 13-39.

Mahmud, M., \& Mirza, N. (2011). An Evaluation of Mutual Fund Performance in an Emerging Economy: The Case of Pakistan. The Lahore Journal of Economics, 16, 301-316.

Mallin, C. A., Saadouni, B., \& Briston, R. J. (1995). The Financial Performance of Ethical Investment Funds. Journal of Business Finance \& Accounting, 22(4), 483-496.

Mansor, F., \& Bhatti, M. I. (2011a). The Islamic Mutual Fund Performance: New Evidence of Market Timing and Stock Selectivity. Paper presented at the 2011 International Conference on Economics and Finance Research Singapore.

Mansor, F., \& Bhatti, M. I. (2011b). Islamic Mutual Fund Performance for Emerging Market, During Bullish and Bearish: The Case of Malaysia. Paper presented at the 2nd International Conference on Business and Economic Research, Kedah, Malaysia.

Mansor, F., \& Bhatti, M. I. (2011c). Risk and Return Analysis on Performance of the Islamic Mutual Funds: Evidence From Malaysia. Global Economy and Finance Journal, 4(1), 19-31.

Mansor, F., Bhatti, M. I., \& Khan, H. (2012). Islamic Mutual Fund Performance: A Panel Analysis. Paper presented at the 2nd Malaysian Postgraduate Conference, Bond University, Queensland, Australia. 
Markowitz, H. (1952). Portfolio Selection. The Journal of Finance, 7(1), 77-91. https://doi.org/10.1111/j.1540-6261.1952.tb01525.x

McGowan, C. B., \& Muhammad, J. (2010). The Theoretical Impact Of The Listing Of Syariah Approved Stocks on Stock Price and Trading Volume. International Business and Economics Research Journal, 9(3), 10.

Merdad, H., Hassan, M. K., \& Alhenawi, Y. (2010). Islamic Versus Conventional Mutual Funds' Performance in Saudi Arabia: A Case Study. J. KAU: Islamic Economics, 23(2), 157-193.

Merton, R. C. (1987). A Simple Model of Capital Market Equilibrium With Incomplete Information. The Journal of Finance, 42(3), 483-150. https://doi.org/10.1111/j.1540-6261.1987.tb04565.x

Nainggolan, Y. (2011). Taking A Leap Of Faith: Are Investors Left Short Changed. Degree of Doctor of Philosophy, Queensland University of Technology, Brisbane, Australia.

Nathie, M. (2008). Embracing Islamic Investment in Australia Using the Malaysian Model: Challenges and Opportunity in The Challenges and Opportunities of Islam in the West: The Case of Australia conference conducted at Griffith $\quad$ University. $\quad$ Retrieved from http://www.griffith.edu.au/_data/assets/pdf_file/0017/66014/Magniid-Conference-Article.pdf

Orlitzky, M., Schmidt, F. L., \& Rynes, S. L. (2003). Corporate Social and Financial Performance: A Meta-analysis. Organization Studies, 24(3), 403-441. https://doi.org/10.1177/0170840603024003910

Pok, W. C. (2012) Analysis of Syariah Quantitative Screening Norms Among Malaysia Syariah-Compliant Stocks. Investment Management and Financial Innovations, 9(2), 69-80.

Rahman, A. A., Yahya, M. A., \& Nasir, M. H. M. (2010, August). Islamic Norms For Stock Screening: A Comparison Between The Kuala Lumpur Stock Exchange Islamic Index And The Dow Jones Islamic Market Index, International Journal of Islamic and Middle Eastern and Management, 3, 228-240. https://doi.org/10.1108/17538391011072426

Razzaq, N., Gul, S., Sajid, M., Mughal, S., \& Bukhari, S. A. (2012). Performance of Islamic Mutual Funds in Pakistan. Economics and Finance Review, 2(3), 16-25.

Renneboog, L., Ter Horst, J. R., \& Zhang, C. (2008a). The Price of Ethics and Stakeholder Governance: The Performance of Socially Responsible Mutual Funds. Journal of Corporate Finance, 14(3), 302-322.

Renneboog, L., Ter Horst, J. R., \& Zhang, C. (2008b). Socially Responsible Investmens: Institutional Aspects, Performance and Investor Behavior. Journal of Banking \& Finance, 32, 1723-1742. https://doi.org/10.1016/j.jbankfin.2007.12.039

Richardson, B. (2007). Do The Fiduciary Duties Of Pension Funds Hinder Socially Responsible Investment?. Banking and Finance Law Review, 22(2), 145-201.

Sadeghi, M. (2008). Financial Performance of Shariah Compliant Investment: Evidence from Malaysian Stock Market. International Research Journal of Finance and Economics, 20(2), 15-26.

Schroder, M. (2004). The Performance of Socially Responsible Investments: Investment Funds and Indices. Financial Markets and Portfolio management, 18(2), 122-142. https://doi.org/10.1007/s11408-004-0202-1

Securities Commission Malaysia. (2015). List of Shariah-compliant Securities by the Shariah Advisory Council of the Securities Commission Malaysia, November 2015, 1-35.

Shamsuddin, A. (2014). Are Dow Jones Islamic Equity Indices Exposed to Interest Rate Risk?. Economic Modelling, 39, 273-281. https://doi.org/10.1016/j.econmod.2014.03.007

Shleifer, A. (1986). Do Demand Curves For Stock Slope Down?. Journal of Finance, 41, 28-30.

Stoll. (1978). The Pricing of Security Dealer Services: An Empirical Study of NASDAQ Stocks. The Journal of Finance, XXXIII(4). https://doi.org/10.1111/j.1540-6261.1978.tb02054.x

Visaltanachoti, N., Zou, L., \& Zheng, Q. (2009). The Performance of "Sin" Stocks in China. Working paper. Massey University.

Wong, T. (2013). Shariah Non-Compliant Stocks: Strategy Flash Note: CIMB.

Yazi, E., Morni, F., \& Imm, S. S (2015). The Effects of Shariah Compliance Announcement Towards Stock Prices Changes In Malaysia. Journal of Economics, Business and Management, 3(11), 1019-1023. https://doi.org/10.7763/JOEBM.2015.V3.327 